\title{
Treatment of skin lesions in newborn children: meeting the needs of nursing staff
}

\author{
TRATAMENTO DE LESÕES DE PELE EM RECÉM-NASCIDOS: CONHECENDO AS \\ NECESSIDADES DA EQUIPE DE ENFERMAGEM
}

TRATAMIENTO DE LESIONES DE PIEL EN RECIÉN NACIDOS: CONOCIENDO LAS
NECESIDADES DEL EQUIPO DE ENFERMERÍA

Simone Vidal Santos ${ }^{1}$, Roberta Costa ${ }^{2}$

\begin{abstract}
Objective: to understand, together with nursing staff, the care needed to treat skin lesions in newborn children hospitalized in a neonatal unit. Method: qualitative research, of the convergent care type. The data was collected through semi-structured interviews, which were conducted from November to December 2012, in the neonatal unit of a hospital in southern Brazil. The participants were four auxiliary nurses, six nursing technicians and four nurses. Results: the following three categories were designated: questions about what can be used in relation to newborn children; hospitalization can cause lesions on the skin of newborn children; and knowledge about care promotes professional autonomy. Conclusion: there is an urgent need for staff to know more about the treatment of skin lesions, which would provide safer care for newborn children and would also support the autonomy of professional nurses in providing that care.
\end{abstract}

\section{RESUMO}

Objetivo: Conhecer, junto à equipe de enfermagem, os cuidados necessários para tratamento de lesões de pele em recémnascidos internados em uma Unidade Neonatal. Método: Pesquisa qualitativa do tipo Convergente Assistencial. Os dados foram obtidos por meio de entrevistas semiestruturadas, realizadas nos meses de novembro a dezembro de 2012, na Unidade Neonatal de um hospital do Sul do Brasil. Participaram da pesquisa quatro auxiliares de enfermagem, seis técnicos de enfermagem e quatro enfermeiras. Resultados: Originaram-se três categorias: dúvidas sobre o que se pode utilizar no recém-nascido; a internação pode acarretar lesões na pele do recém-nascido; e o conhecimento do cuidado promove autonomia profissional. Conclusão: Torna-se urgente a necessidade de conhecimento da equipe sobre o tratamento de lesões, propiciando o atendimento mais seguro ao recém-nascido e favorecendo a autonomia do profissional enfermeiro na realização do cuidado.

\section{DESCRIPTORS}

Infant newborn

Skin

Wounds and injuries

Therapeutics

Neonatal nursing

\author{
DESCRITORES \\ Recém-nascido \\ Pele \\ Ferimentos e lesões \\ Terapêutica \\ Enfermagem neonatal
}

\section{RESUMEN}

Objetivo: Conocer, junto al equipo de enfermería, los cuidados necesarios para el tratamiento de lesiones de piel en recién nacidos internados en una Unidad Neonatal. Método: Investigación cualitativa del tipo Convergente Asistencial. Los datos fueron obtenidos por medio de entrevistas semiestructuradas, realizadas en los meses de noviembre a deciembre de 2012, en la Unidad Neonatal de un hospital del Sur de Brasil. Participaron de la investigación cuatro auxiliares de enfermería, seis técnicos de enfermería y cuatro enfermeras. Resultados: Se originaron tres categorías: dudas acerca de lo que se puede utilizar en el recién nacido; la estancia hospitalaria puede causar lesiones en la piel del recién nacido; y el conocimiento del cuidado promueve autonomía profesional. Conclusión: Se hace urgente la necesidad de conocimiento del equipo acerca del tratamiento de las lesiones, a fin de proporcionar una atención más segura al recién nacido y favorecer la autonomía del profesional enfermero en la puesta en marcha del cuidado.

\section{DESCRIPTORES \\ Recién nacido \\ Piel \\ Heridas y traumatismos \\ Terapéutica \\ Enfermería neonatal}

\footnotetext{
* Extracted from the MA dissertation "Guia para prevenção e tratamento de lesões de pele em recém-nascidos internados em Unidade de Terapia Intensiva Neonatal: uma construção coletiva da equipe de enfermagem”, MA in the professional management of care in nursing, Federal University of Santa Catarina, Florianópolis, SC 2014. ${ }^{1}$ MA in nursing, University Hospital, Federal University of Santa Catarina, Florianópolis, Brazil. ${ }^{2}$ Professor, PhD, Department of Nursing, Federal University of Santa Catarina, Florianópolis, Brazil.
} 


\section{INTRODUCTION}

The skin is the largest organ of the human body and also one of the most active. It comprises the epidermis and dermis; two layers that are firmly bonded and which overlay the subcutaneous tissue ${ }^{(1)}$. The epidermis consists of four layers, and the outermost, the stratum corneum, is responsible for a valuable contribution to the protection of the skin because it acts as a barrier against transepidermal fluid loss and invasion by agents of the external environment ${ }^{(1-2)}$. The dermis is primarily composed of collagen and elastin fibres, which provide support, elasticity and resilience to the $\mathrm{skin}^{(1)}$.

The epidermal barrier begins to form in the womb and its histological development is complete at 34 weeks of gestation. At birth, the stratum corneum of newborn children resembles that of adults, with adherent cells, while in preterm infants there are few layers of stratum corneum and the cells are thinner and less compact ${ }^{(2-3)}$. In both preterm and newborn children the dermis has fewer elastic fibres, and the dermal-epidermal junction is poor and has high permeability due to a higher body surface area to weight ratio. These factors expose newborn children to a higher risk of developing lesions, percutaneous absorption of chemicals, and reaction to irritating substances ${ }^{(3)}$.

Newborn children who are hospitalized in neonatal intensive care units (NICU) have a higher risk of suffering skin lesions. In order to provide correct treatment, nurses should eliminate or control the causative factors and provide a favorable environment for healing ${ }^{(4-5)}$.

Working as nurses in a NICU in a hospital in southern Brazil, the authors of this study realized that there are constant worries and concerns on the part of the nursing staff about the skin care for hospitalized newborn children. These professionals report that there is no standard treatment for lesions, or systematic assessment and monitoring of their evolution, which means that diverse strategies are adopted during care. This gives rise to the following question: what type of care does the nursing staff in NICUs consider to be important and necessary to treat skin lesions in hospitalized newborn children? To answer this question it was decided to carry out this research with the objective of learning, with the help of nursing staff, what type of treatment is required to treat skin lesions in newborn children hospitalized in a neonatal intensive care unit in southern Brazil.

\section{METHOD}

This is a qualitative, convergent care-type study (CCS). The data was collected through semi-structured interviews, which followed a script with open and closed questions regarding issues related to the identification of the participants and their time working in the NICU. There were also questions related to the skin care of hospitalized newborn children, which were formulated based on the professional experience of the researchers and the existing literature on the subject ${ }^{(6)}$. The research was conducted in the NICU of a hospital in southern Brazil, which has 16 inpatient beds. However, during the period of data collection the unit was undergoing renovations and its capacity and the number of professionals working there had been reduced. The data was collected from November to December 2012.

The individuals who participated in the study were the professionals of the nursing staff who worked in the NICU that were working in the period in which the data was collected. Professionals who were on vacation, maternity leave, or who withdrew due to illness were excluded. Thus, four auxiliary nurses, six nursing technicians and four nurses participated in the study. All were invited to participate in the study during their working hours, and interviews were conducted in the nursing rest room, a private environment that permitted privacy between interviewee and interviewer. The procedure for data collection was terminated when the researcher noticed the repetition of information obtained in the interviews, showing that there was data saturation and that no new understanding about the topic under investigation was being achieved ${ }^{(7)}$.

The study was approved by the Ethics Committee of the Federal University of Santa Catarina in opinion No. $34574 / 2012$ and it conformed to the ethical precepts required in human research. The interviews were recorded and the participants signed an informed consent and authorization for recording the interviews. To preserve anonymity, the participants were identified with the names of flowers.

The basis for this CCS analysis was the interviews with the participants of the study, which initially involved the process of transcription and reading of data, allowing the identification of the key words according to the study objectives. This was followed by the synthesis, which entailed a deep reading of the data, allowing the common information to be grouped, which in turn enabled the development of codes that, according to the objectives of the study, allowed the construction of categories. Theorizing then occurred and the theoretical framework was used to interpret the categories and formulate the final considerations of the study. Finally, re-contextualisation was performed, during which the data were socialized ${ }^{(8)}$.

\section{RESULTS}

Most respondents were female (92.8\%), aged between 25 and 55, and more than half of the respondents were over 40 (64.3\%). Regarding the level of education, seven had completed high school (50\%) and seven had higher education (50\%), of which five had completed postgraduate courses at MA level (35.7\%). Regarding their time
Treatment of skin lesions in newborn children: meeting the needs of nursing staff Santos SV, Costa R 
working in a NICU, most of the participants had worked in the field for more than ten years (64.3\%).

The interviews lasted between six and twenty minutes. The following three categories emerged from the collected data: doubts about what can be used in newborn children; hospitalization can cause lesions on the skin of newborn children; knowledge about care promotes professional autonomy.

\section{Doubts about what can be used in newborn children}

The scarcity of information about skin lesions in newborn children was noted, which can generate insecurity in the nursing team and directly affect the quality of care, as evidenced by the following statement:

(...) I saw a case (...) actually it was an extensive, severe, grade 2 injury, a burn with oximetry sensor. So we wondered: what should we be using? Only, when I saw it, it had already been a few days, so we had some doubts. So what people use is what that they have already been using for a while (Hibisco).

The insecurity of the nursing staff regarding the treatment of injuries was not only concerning the choice of special dressings, but also the use of other topical agents, as shown in the following:

(...) there was a baby that we used ointment on (...). He was using the ointment on the jaw because the baby had candidiasis. Later on he ended up causing a lesion because of the ointment itself, but in the region where there was no candidiasis. So you also have to be take care with the use of ointments (Hibisco).

For the team, treatment with topical agents becomes even more difficult when newborn children are treated under phototherapy, as seen in the following extract:

(...) Then there is phototherapy, which you have to be so careful with (...). You can't use any kind of oil, EFA(essential fatty acids), you can't use anything, right? (Flor de Laranjeira).

\section{Hospitalization can cause lesions on the skin of newborn children}

Extravasation was also a problem mentioned by the nursing staff in this study:

(...) extravasation, there aren't many lesions now (...). We have had it [extravasation] and when it occurs it is usually associated with the administration of antibiotics, especially vancomycin, which I imagine is due to its low $\mathrm{pH}$, because it causes lesions, even necrosis, and then nobody knows what to do. Sometimes we apply KCL (potassium chloride) topic at the time of the extravasation, and then we keep an eye on it. Once, we had to use that vasodilator, nitroglycerin, to improve vascularization in that place, but we didn't really know what reactions it might create (Amor-perfeito).

The following illustrates the doubts and concerns of staff regarding the management of lesions caused by extravasation:
(...) these issues of the treatment of skin lesions (...) on this same issue, if there is already a lesion, if it extravasates, what should we do? Heat, cold, closed, not closed, left open (...) what are you supposed to do? (Hibisco).

Apart from intravenous extravasation, another type of lesion that was identified in reports from the nursing staff as being difficult to manage was lesions of the nasal septum, mainly related to the use of nasal continuous positive airway pressure (CPAP):

(...) Our main problem today is related to catheter use and CPAP, which is where the most frequent lesions occur (...). We have already used hydrocolloid boards in the nasal septum, but it is still pretty confusing (...) and there really are lesions (...) there are babies without a nasal septum (...) (Orquídea).

The above extract shows that the nursing staff uses measures to protect the nostrils of newborn children. However, lesions of the nasal septum occur despite these precautions, causing insecurity and doubt about the proper management of the use of this device in newborn children.

(...) lesions of the septum are what are happening now and they of most relevance to us (...). Usually it is because the cap rises, because we still do not have an adequate model of extranasal catheter fixation (...) (Jasmim).

Another injury that causes great concern for the nursing staff is perineal dermatitis because newborn children have no sphincter control and require the use of diapers. The team have experienced difficulty in caring for this lesion, as can be seen from the following:

(...) there is no consensus about using diapers: someone puts one on, somebody else takes it off. There is not enough debate about this and otherwise it is: someone puts one on, somebody else takes it off. Because of this I think that children are not getting better quickly (Rosa Amarela).

(...) The greatest number of lesions is associated with perianal hyperaemia, and compromises in integrity due to the overuse of antibiotics. There is frequent bowel movement, and then we see that diaper changes every 3 hours may not be enough, or the attention that is given (...) (Amor-perfeito).

\section{Knowledge about care promotes professional autonomy}

In the search for autonomy, the team attempts to organize nursing care in the treatment of skin lesions in newborn children. Knowledge is one of the concerns of those who participated in this study. In view of the team, knowledge is the basis for the care of newborn children; as professionals they will only be able to provide safe and efficient care when they clearly understand the objectives of their actions.

(...) some people already have the knowledge, others not; without knowledge it is difficult because you don't understand the importance of things do you? (...) (Amor-perfeito).

I believe that caregivers have to know what they are doing; what will stick to a baby's skin? if it will irritate the 
skin or not? Care is the basis; it can both harm and improve (...) (Lírio).

In the discourse of the nursing staff, proper evaluation of newborn children begins with the first observation of the patient:

\section{(...) I think from the moment that you look into a baby's eyes, observation is part of care; it's the main thing actu- ally (...). You're analyzing the baby's chart, seeing if they already have any risk factor; that is already part of care- giving. Seeing if they have anaemia, is it a baby that's alre- ady been exposed to antibiotics? The other things that can hinder healing (...) (Hibisco).}

As well as correct assessment, another concern that was evident in the reports of the respondents was about nursing records:

\begin{abstract}
(...) As nurses, we made daily records and I think that this was very important. It's about learning to register with effectiveness, to read lesions. I think that this is something that we have difficulty with, so if you verbally pass on the call but you cannot describe exactly what is involved, you do not have a checklist, which is what I need to have knowledge about that lesion (...). Nursing is a very special type of care, but it's not very good at recording information (Bromélia).
\end{abstract}

It appears that there is no organization in the care of newborn children with skin lesions, which hinders decision making by nurses and also the continuity of care by nursing staff, as can be seen in the following extract:

(...) in most cases, they (nursing auxiliaries/technicians) ask for the nurse to accompany them and the nurse ends up prescribing, but I see that often this treatment is modified and that's not justified (...). It's not right to wait for 24 hours to see if a particular treatments leads to a favorable or unfavorable outcome (Amor-perfeito).

\section{DISCUSSION}

\section{Doubts about what can be used in newborn children}

The evaluation and treatment of lesions are the responsibilities of nurses and they should therefore know all the factors involved in this process in order to properly diagnose and select the ideal product for healing to occur ${ }^{(9)}$.

In recent years, technologies for treating lesions have evolved considerably, especially in the development of special dressings. Currently, there are many sophisticated products available on the market, which can cause some confusion at the time of choice ${ }^{(1)}$. Technological advances in the care of lesions require that professional nursing teams have greater scientific knowledge to improve their practice, gather resources and provide quality care ${ }^{(9)}$. However, there is little information regarding the use of technologies for this purpose in relation to newborn children ${ }^{(10)}$.
The ideal dressing for a lesion changes according to the evolution of the lesion itself. The choice of the product depends on the type of tissue that lies on the bed of the lesion, the depth of the lesion, the amount of exudates, and the presence of signs of local infection $^{(5)}$. It is necessary to select a product that provides an adequate environment for healing by maintaining adequate moisture. The product should also offer protection against bacterial invasion, be easy to apply, adapt and remove, provide patient comfort and not require frequent changing(1).

The Association of Women's Health, Obstetric and Neonatal Nurses (AWHONN) $)^{(10)}$ issued revised Guidelines in 2013 that recommend adhesive dressings based on silicone, polyurethane film, or hydrocolloid or hydrogel dressings to treat skin lesions in newborn children. These can be used safely on neonatal patients and they provide moisture control, autolytic debridement and fill dead space, which all contribute to the optimization of the healing process $^{(1)}$.

In lesions with signs of infection, such as swelling, heat, pain, excessive erythema, and the presence of rash, pustules or vesicles, culture tests should be performed to identify the pathogen and to provide the appropriate antimicrobial treatment ${ }^{(10)}$.

The use of silver-based dressings to treat infected lesions in newborn children has been little discussed in the literature. Only one study was found ${ }^{(5)}$ regarding the effectiveness of the use of this product in newborn children and there is no evidence to ensure the absence of longterm risks in using this type of dressing.

The stratum corneum, the outermost layer of the epidermis, acts as a barrier for the skin. Babies with less than 34 weeks gestational age (GA) have thinner and more immature strata cornea, which allows water to pass from the inside to the outside of the body, and substances applied to the skin are potentially absorbed, which can cause toxicity ${ }^{(5,11)}$.

The use of alcohol or iodine-based products for skin antisepsis before invasive procedures can cause irritation, extensive burns and poisoning in newborn children ${ }^{(12)}$. The most recommended product is chlorhexidine gluconate, an antiseptic widely used in adults and children that can be prepared in aqueous or alcoholic form ${ }^{(10)}$. In order to prevent chemical lesions on the skin of newborn children, it is recommended to use a small quantity of $0.5 \%$ alcoholic chlorhexidine, but the solution must be removed immediately after the procedure by cleaning the area with sterile distilled water ${ }^{(13)}$. Aqueous chlorhexidine prevents chemical burns and is recommended for use in extremely preterm infants $^{(14)}$.

The use of silver sulfadiazine cream is contraindicated for children less than two months of age because it contains sulphur, which competes with bilirubin to bind
Treatment of skin lesions in newborn children: meeting the needs of nursing staff Santos SV, Costa R 
to albumin. The circulating bilirubin is available to be absorbed by the blood-brain barrier, with the potential risk to cause kernicterus. Topical formulations of corticosteroids may cause Cushing's syndrome, with dermal atrophy, adrenal suppression and systemic toxicity ${ }^{(15)}$.

Antifungal ointments may be used in the treatment of fungal infections in newborn children. Antibiotics ointments can be useful in the treatment of gram-positive bacteria, but they may also cause an increase in gramnegative bacteria. They can also cause sensitization and therefore should be used sparingly and cautiously in newborn children ${ }^{(10)}$.

Emollients can be used on the skin of newborn children because they are recommended for the protection and maintenance of the barrier function provided by the skin $^{(10)}$; however, attention should be paid to the development of infections during their use. In the case of newborn children undergoing phototherapy, there is duality of recommendations. Although there is little evidence of the occurrence of burns or hyperthermia when emollients are applied in newborn children undergoing phototherapy ${ }^{(10)}$, one study has warned that ointments or creams should not be applied to the skin of newborn children because of the risk of burns ${ }^{(16)}$. Thus, particular caution is advised in the use of topical medications on the skin of newborn children undergoing phototherapy.

\section{Hospitalization can cause lesions on the skin of newborn children}

Newborn children hospitalized in NICUs are in constant risk of skin lesions due to their anatomy, physiology, and the need for use of invasive procedures that are essential for their survival(4). The most common adverse occurrence in newborn children is intravenous extravasation, in which there is inadvertent leakage of fluids or medications into the surrounding tissue, rather than the intended vascular area ${ }^{(10,12)}$. Its incidence ranges from $23-63 \%$ and it can cause the partial or total loss of skin and muscle. It can also cause nerve damage and have an adverse effect on functional and aesthetic aspects ${ }^{(12)}$.

Some scales can be used to assist in the evaluation and treatment of intravenous extravasation, including the Milligram Scale of Intravenous infiltrations ${ }^{(17)}$ and Thigpen's Grading Scale of Intravenous Infiltrations ${ }^{(18)}$. Although the use of scales is recommended in the literature, a study conducted in the city of Cuiabá, Mato Grosso, Brazil(19) showed that the nurses did not use instruments that could help in the assessment and treatment of intravenous extravasation. Incidentally, this study showed that case management was performed without scientific basis, demonstrating that there was confusion regarding the choice of treatment when there were different complications.

There was also no evidence found in the literature regarding the use of $\mathrm{KCL}$ for the treatment of intravenous extravasation. Although the topical use of nitroglycerin is recommended because of its vasodilating action, which leads to a decrease in tissue ischemia, this medicine may cause hypotension; it should be used with caution in children and it requires continuous hemodynamic monitoring during use $\mathrm{e}^{(10,20)}$.

The use of hot or cold compresses should be discouraged; as well as the risk of causing thermal damage to immature skin, there is no evidence to support or refute their use in cases of intravenous infiltration in newborn children ${ }^{(10)}$. In order to prevent further tissue damage, interruption of the infusion is recommended at the slightest sign of leakage, as well as elevation of the affected area in order to promote venous return and the reabsorption of fluid. The subcutaneous administration of hyaluronidase, an enzyme which temporarily reduces the viscosity of the intercellular cement and promotes the absorption of extravasated fluids, is also recommended because it decreases tissue damage by toxic substances ${ }^{(10,20)}$.

Lesions due to extravasation can cause pain, infection and increased morbidity. They may also prolong the length of hospitalization, with a consequent increase in hospital costs. Preventive measures and immediate actions reduce the risk of these types of lesions ${ }^{(21)}$ and nurses need to absorb new knowledge in order to advance the quality of care ${ }^{(19)}$.

Nasal CPAP is a device that was created to assist in the treatment of problems related to lung immaturity in preterm infants; however, its use is not without complications $^{(22)}$. The use of CPAP to treat secondary nasal lesions has been reported since 1980 and its incidence ranges from 20 to $60 \%$. The factors that contribute to its onset are related to the choice, application and maintenance of the device ${ }^{(12)}$.

It is recommended that the system (prongs and tracheas) is used only once, because its disinfection can cause wear, making it more rigid and less flexible. Furthermore, it should be well stabilized because its mobility and trauma causes pressure inside the nostrils. The use of adhesive protection between the nostrils and the prongs avoids direct friction and can relieve pressure and prevent lesions ${ }^{(23)}$. The integrity of the skin should be routinely inspected, which provides an early diagnosis and the ability to adopt measures to prevent lesions related to the use of this device. To reduce the risk of irritation and inflammation of the fragile mucosa of newborn children during nasal aspiration, a catheter with a caliber smaller than 5 $\mathrm{mm}$ should be used ${ }^{(24)}$.

Based on the literature ${ }^{(12)}$, it is clear that the occurrence of nasal lesions due to CPAP use is common; however, prevention of these lesions is not limited to the protection of the nostrils. Nursing staff should also be attentive to the selection, suitability, fixing and maintenance of this device in the fragile skin of preterm infants. In order to 
direct patient care, nurses must be familiar with the technologies that are available, as well as being aware of the specific needs of their patients ${ }^{(25)}$.

Dermatitis in the diaper area is another lesion that affects newborn children and infants, and if it is not properly treated it can progress rapidly. This type of dermatitis occurs due to increased temperature and humidity through diaper use, which leads to maceration of the skin, leaving it vulnerable to irritation caused by contact with feces and urine ${ }^{(3)}$. Some of the most common risk factors for developing dermatitis are frequent bowel movements, the use of antibiotics, and malabsorption; constant evaluation contributes to early detection and proper treatment ${ }^{(10)}$.

With regard to prevention, the use of absorbent diapers and frequent changes are recommended in order to reduce moisture and contact with the enzymes present in the feces, which helps to maintain the ideal $\mathrm{pH}$ for perineal skin. Cleaning of the area should be performed gently, preferably using soft cloth or cotton balls soaked in warm water, which prevents the properties of the skin barrier from being damaged. Emollients or zinc oxide pastes help to form a topical barrier, which protects the skin from irritants, minimizes friction and reduces the risk of dermatitis ${ }^{(26)}$.

For the treatment of dermatitis to be efficient, it must identify and treat the underlying causes, protect the skin lesions by applying creams that promote a skin barrier, and identify and treat any lesions that are complicated by fungus with anti-fungal ointment. The effectiveness of the treatment needs to be evaluated and, in the absence of a positive response, allergic dermatitis should be considered as a potential diagnosis ${ }^{(10)}$.

There are many recommendations for the management of perineal dermatitis. The ideal form of care is conditioned by the knowledge of the nursing staff regarding pathophysiology, risk factors, and the preventive and curative measures of this pathology. The correct evaluation of the skin, and the consensus of the nursing staff on the actions to be implemented in the management of lesions in newborn children, is fundamental to the quality of care and successful treatment in neonatology.

\section{Knowledge about care promotes professional autonomy}

The effective care of skin lesions in newborn children is a challenge for neonatal staff because it requires a practice that is based on informed knowledge of the scientific literature, with in-depth information related to the skin and its characteristics: these factors are essential in planning quality care ${ }^{(27)}$. Planning and organizing care in a holistic, objective and standardized way is one of the factors which provide autonomy to nurses; however, this autonomy still depends on the knowledge of the professional, and their confidence in performing their duties ${ }^{(28)}$.

Neonatal nurses need to know about the characteristics of skin that is prone to lesions, the mechanisms of lesions, the physiology of healing, and the factors that affect it. They should also know about the assessment and the treatment of lesions, based on the best evidence to restore function and appearance with a minimum of complications $^{(5)}$.

Correct assessment will direct the optimal treatment for lesions. An evaluation is required of the cause of the lesion, the time it occurred, its depth, the type of tissue present in the bed of the lesion, the anatomical location, the size, the characteristics of the exudates and the perilesional area, as well as signs of pain and stress. The use of a tool to evaluate lesions provides a systematic approach, which improves communication between staff and enables the choice of the most appropriate treatment ${ }^{(5)}$.

Nursing staff need tools that can assist in the evaluation and proper recording of lesions. Nursing records are an important tool of communication between staff; they are essential for planning care and to indicate the continuity and individuality of care ${ }^{(29)}$.

In the hospital where this research was conducted, the systematization of nursing care (SNC) method is used and nurses develop and prescribe care on a daily basis. SNC is a tool that contributes to the quality of care; it assists in the organization of nursing work and promotes professional autonomy.

The organization of work and the planning of care are essential in nursing, especially when working in a NICU, which requires qualified, personalized care that minimizes risks to newborn children ${ }^{(30)}$.

Systematizing and standardizing nursing care, based on the construction of guidelines related to the skin care of preterm infants, are important measures to reduce the risks of changes in professional behavior and to reduce the appearance of skin lesions; they allow the individualization and humanization of care to newborn children to be prioritized ${ }^{(30)}$. The need for this systematization and standardization was explicitly referred to in the discourses of the individuals who participated in this study as representing a valuable contribution to direct the actions of staff working in neonatal nursing to provide safe and qualified care, well-organized work, as well as providing autonomy to the nurses who work in NICUs.

\section{CONCLUSION}

Newborn children have several characteristics that can result in lesions. The aim of this study was to identify the needs of nursing staff regarding the treatment of skin lesions in newborn children. It was found that these relate to greater knowledge about the following: the recommendation and use of special coatings; topical agents; the treatment of lesions in newborn children undergoing phototherapy; the management of lesions related to intravenous extravasation; nasal septum lesions; dermatitis in the diaper
Treatment of skin lesions in newborn children: meeting the needs of nursing staff Santos SV, Costa R 
area; a better understanding of the specifics of the skin; the assessment of lesions and the organization of care.

The results revealed that the team was undergoing difficulties in treating skin lesions in newborn children. In their interviews, it became clear that the lack of standardization of approach hampers the decision making and continuity of care provided to newborn children, which impairs the autonomy of nurses working in the field. The findings also indicate that professionals crave more knowledge about this issue and are concerned about improving the quality of the care that they provide.

Based on the interviews conducted in this study, as well as the literature regarding the treatment of skin lesions in hospitalized newborn children, it is evident that there is an urgent need for more knowledge and better organization of work to provide safe and qualified care for hospitalized newborn children, which will also result in greater autonomy for professional nurses.

As nurses working in a NICU, we face daily difficulties regarding the skin care of newborn children. The

\section{REFERENCES}

1. Dealey C. The care of wounds: a guide for nurses. 4th ed. San Francisco, CA: Wiley-Blackwell; 2012.

2. Afsar FS. Physiological skin conditions of preterm and term neonates. Clin Exp Dermatol. 2010;35(4):346-50.

3. Sarkar R, Basu S, Agrawal RK, Gupta P. Skin care for the newborn. Indian Pediatr. 2010;47(7):593-8.

4. Rolim KMC, Barbosa RMA, Medeiros RMG, Leite ML, Gurgel EPP. Permanência da membrana semipermeável na pele do recém-nascido: um cuidado diferenciado. Rev RENE. 2010;11(1):144-51.

5. Fox MD. Wound care in the neonatal intensive care unit. Neonatal Netw. 2011;30(5): 291-303.

6. Association of Women's Health, Obstetric and Neonatal Nurses. Neonatal skin care: evidence-based clinical practice guideline. Washington, DC: AWHONN; 2007.

7. Fontanella BJB, Ricas J, Turato ER. Amostragem por saturação em pesquisas qualitativas em saúde. Cad Saúde Pública. 2008;24(1):17-27.

8. Trentini M, Paim L. Pesquisa convergente-assistencial: um desenho que une o saber fazer e o saber pensar na prática assistencial em saúde-enfermagem. 2ª ed. Florianópolis: Insular; 2004.

9. Salomé GM. Avaliando lesão: práticas e conhecimentos dos enfermeiros que prestam assistência ao indivíduo com ferida. Saúde Coletiva. 2009;6(35):280-7. specific physiological conditions of newborn children, allied to the lack of studies regarding this population, which is considered to be a vulnerable group, constitute a major barrier to the knowledge of professionals about the appropriate product to use, which generates doubts and significantly increases the concerns of those who work in the direct care of newborn children. Existing studies should be considered and shared. In addition, nursing teams should share their professional experience, and gaps in knowledge should be used to guide future research and practice in the skin care of newborn children.

Scientific evidence about the treatment of skin lesions in newborn children is scarce in the literature. Consequently, it is recommended that new research related to the topic is conducted in order to identify and validate different forms of assistance in neonatology. It is hoped that the specificities and the possibilities related to the care of newborn children will be reflected upon and discussed by nursing staff, with a view to constructing new paradigms to underpin practical assistance.

10. Association of Women's Health, Obstetric and Neonatal Nurses. Neonatal skin care: evidence-based clinical practical guideline. 3rd ed. Washington, DC: AWHONN; 2013.

11. Araújo BBM, Esteves SX, Cardoso ES, Meirelles JNL, Dias $\mathrm{CMB}$. A enfermagem e os (des) cuidados com a pele do prematuro. Rev Pesqui Cuid Fundam. 2012;4(3): 2679-91.

12. Sardesai SR, Kornacka MK, Walas W, Ramanathan R. latrogenic skin injury in the neonatal intensive care unit. J Matern Fetal Neonatal Med. 2011;24(2):197-203.

13. Rolim KMC, Farias CPX, Marques LC, Magalhães FJ, Gurgel EPP, Caetano JA. Atuação da enfermeira na prevenção de lesão de pele do recém-nascido. Rev Enferm UERJ [Internet]. 2009 [2013 jan. 13];17(4):544-9. Disponível em: http:// www.facenf.uerj.br/v17n4/v17n4a16.pdf

14. Brasil. Ministério da Saúde; Secretaria de Atenção à Saúde, Departamento de Ações Programáticas Estratégicas. Atenção à Saúde do Recém-Nascido. Guia para os profissionais de saúde: intervenções comuns, icterícia e infecções. 2 a ed. Brasília; 2013.

15. Bree A, Siegfried E. Neonatal skin care and toxicology. In: Eichenfield LF, Frieden IJ, Esterly NB, editor. Neonatal dermatology.2nded. Philadelphia:SaundersElsevier;2008. p.59-72.

16. Colvero AP, Colvero MO, Fiori RM. Módulo de ensino fototerapia. Sci Med. 2005; 15(2):125-32. 
17. Millam DA. Managing complications of I.V. therapy (continuing education credit). Nursing. 1988;18(3):34-43.

18. ThigpenJ.Peripheralintravenousextravasation:nursingprocedure for initial treatment. Neonatal Netw. 2007;26(6):379-84.

19. Modes PSSA, Gaíva MAM, Rosa MKO, Granjeiro CF. Cuidados de enfermagem nas complicações da punção venosa periférica em recém-nascidos. Rev RENE. 2011;12(2):324-32.

20. Amjad I, Murphy T, Nylander-Houssholder L, Ranft A. A new approach to management of intravenous infiltration in pediatric patients: pathophysiology, classification, and treatment. J Infus Nurs. 2011;34(4):242-9.

21. Lund HC, Kuller JM. Integumentary system. In: Kenner C, Lott JW. Comprehensive neonatal nursing care. 5th ed. New York: Springer; 2013. p. 1026.

22. Antunes JCP, Nascimento MAL, Gomes AVO, Araujo MC, Christofell MM. Tecnologia coadjuvante no tratamento do recém-nato prematuro (cuidados de enfermagem no uso do CPAP nasal). Enferm Global [Internet]. 2010 [citado 2013 dez. 13];20. Disponível em: http://scielo.isciii.es/pdf/eg/ n20/pt_docencia4.pdf

23. Nascimento RM, Ferreira ALC, Coutinho ACFP, Verissimo RCSS. The frequency of nasal injury in newborns due to the use of continuous positive airway pressure with prongs. Rev Latino Am Enfermagem. 2009;17(4):489-94.
24. Sousa NFC, Bonfim SFSF, Vasconcelos MGL, Bezerra JLO, Silva DVC, Leal LP. Prevalence of nasal septum injury in premature infants using nasal prongs. Rev Esc Enferm USP [Internet]. 2013 [cited 2014 Sept 9];47(6):1285-90. Available from: http://www.scielo.br/pdf/reeusp/v47n6/en_0080-6234reeusp-47-6-01285.pdf

25. Silva RC, Ferreira MA. Technology in intensive care and its effects on nurses' actions. Rev Esc Enferm USP [Internet]. 2011 [cited 2013 Aug 13];45(6):1403-11. Available from: http://www.scielo.br/pdf/reeusp/v45n6/en_v45n6a18.pdf

26. Ness MJ, Davis DMR, Carey WA. Neonatal skin care: a concise review. Int J Dermatol. 2013;52(1):14-22.

27. Fontenele FC, Cardoso MVLML. Skin lesions in newborns in the hospital setting: type, size and Affected area. Rev Esc Enferm USP [Internet]. 2011 [cited 2013 Oct 13];45(1):1307. Available from: http://www.scielo.br/pdf/reeusp/v45n1/ en_18.pdf

28. Skar R. The meaning of autonomy in nursing practice. J Clin Nurs. 2010;19(15-16): 2226-34.

29. Wang N, Hailey D, Yu P. Quality of nursing documentation and approaches to its evaluation: a mixed-method systematic review. J Adv Nurs. 2011;67(9):1858-75.

30. Rolim KMC, Linhares DC, Rabelo LS, Gurgel EPP, Magalhães FJ, Caetano JA. Cuidado com a pele do recém-nascido prétermo em Unidade de Terapia Intensiva Neonatal: conhecimento da enfermeira. Rev RENE. 2008;9(4):107-15. 